\title{
The crystal chemistry of elsmoreite from the Hemerdon (Drakelands) mine, UK: hydrokenoelsmoreite-3C and hydrokenoelsmoreite- $6 R$
}

\author{
Stuart J. Mills ${ }^{1, *}$, Andrew G. Christy ${ }^{2, \dagger}$, Mike S. Rumsey ${ }^{3}$ and John Spratt ${ }^{4}$ \\ 1 Geosciences, Museum Victoria, GPO Box 666, Melbourne, Victoria 3001, Australia \\ 2 Department of Applied Mathematics, Research School of Physics and Engineering, Australian National University, \\ Canberra, ACT 2601, Australia \\ 3 Earth and Planetary Mineralogy Division, Department of Earth Sciences, Natural History Museum, Cromwell Road, \\ London SW7 5BD, UK \\ 4 Core Research Laboratories, Facilities Department, Natural History Museum, Cromwell Road, London SW7 5BD, \\ UK
}

[Received 6 August 2015; Accepted 10 November 2015; Associate Editor: Juraj Majzlan]

\section{ABSTRACT}

A crystallographic and chemical study of two 'elsmoreite' samples (previously described as 'ferritungstite') from the Hemerdon mine (now known as the Drakelands mine), Devon, United Kingdom has shown them to be two different polytypes of hydrokenoelsmoreite. Hydrokenoelsmoreite-3C (HKE-3C) crystallizes in space group $F d \overline{3} m$, with the unit-cell parameter $a=10.3065(3) \AA$. Hydrokenoelsmoreite- $6 R$ (HKE- $6 R$ ) crystallizes in space group $R \overline{3}$, with the unit-cell parameters $a=7.2882(2) \AA$ and $c=35.7056(14) \AA$. Chemical analyses showed that both polytypes have $\mathrm{Na}$ and $\mathrm{Fe} / \mathrm{Al}$ substitution giving the formulae: $\left(\mathrm{Na}_{0.28} \mathrm{Ca}_{0.04} \mathrm{~K}_{0.02}\left(\mathrm{H}_{2} \mathrm{O}\right)_{0.20} \square_{1.46}\right)_{\sum 2.00}\left(\mathrm{~W}_{1.47} \mathrm{Fe}_{0.32}^{3+} \mathrm{Al}_{0.21} \mathrm{As}_{0.01}^{5+}\right)_{\sum 2.00}\left[\mathrm{O}_{4.79}(\mathrm{OH})_{1.21}\right]_{\sum 6.00}\left(\mathrm{H}_{2} \mathrm{O}\right)$ (3C) and $\left(\mathrm{Na}_{0.24} \mathrm{Ca}_{0.04} \mathrm{~K}_{0.03}\left(\mathrm{H}_{2} \mathrm{O}\right)_{0.63} \square_{1.06}\right)_{\sum 2.00}\left(\mathrm{~W}_{1.42} \mathrm{Fe}_{0.49}^{3+} \mathrm{Al}_{0.08} \mathrm{As}_{0.01}^{5+}\right)_{\sum 2.00}\left[\mathrm{O}_{4.65}(\mathrm{OH})_{1.35}\right]_{\sum 6.00}\left(\mathrm{H}_{2} \mathrm{O}\right)$ (6R). The doubling of the unit cell in the $6 R$ phase is due to ordering of $\mathrm{Na}$ and $\left(\square, \mathrm{H}_{2} \mathrm{O}\right)$ in the $A$ site; no long-range ordering is observed between $\mathrm{W}$ and $\mathrm{Fe} / \mathrm{Al}$ in the $B$ site.

KEYWORDs: pyrochlore, elsmoreite, pittongite, phyllotungstite, crystal structure, tungstate.

\section{Introduction}

As part of our ongoing study into platy secondary tungstate phases (Grey et al., 2006; Birch et al., 2007), we identified for additional study two samples labelled 'ferritungstite' but with platy morphology similar to pittongite, from the Hemerdon mine (now known as Drakelands mine), $10 \mathrm{~km}$ E of Plymouth, Devon, United Kingdom $\left(50^{\circ} 24^{\prime} 26^{\prime \prime} \mathrm{N}, 4^{\circ} 0^{\prime} 35^{\prime \prime} \mathrm{W}\right)$.

\footnotetext{
*E-mail: smills@museum.vic.gov.au

${ }^{\dagger}$ Current address: Queensland Museum, 122 Gerler Road, Hendra, Queensland 4011, and School of Earth Sciences, University of Queensland, St Lucia, Queensland 4072, Australia

DOI: $10.1180 /$ minmag.2016.080.058
}

The specimens (Fig. 1) are registered within the collections at the Natural History Museum, London as BM 2006,118 and BM 2008,56.

The W-Sn deposit at the Hemerdon (Drakelands) mine was discovered in the $19^{\text {th }}$ Century and was operated most extensively during the two world wars. It worked a greisen vein system and stockwork within the Hemerdon Bal granite cupola and surrounding 'killas' (metamorphosed Devonian slates) via a mixture of opencast and underground mining (Cameron, 1951). The upper part of the deposit is heavily altered and has produced a wealth of secondary minerals, with particularly fine examples of scorodite, pharmacosiderite and minor amounts of the tungstates russellite and 'elsmoreite' (often labelled as 'ferri-' or 'alumotungstite'). The mine is currently in the process of being redeveloped as a 
large opencast mine, which will be the first new metal mine in the United Kingdom for nearly 50 years.

The platy habit of these specimens, despite their cubic $(3 C)$ or pseudocubic $(6 R)$ crystal symmetry, strongly suggests that they are pseudomorphs after a non-cubic precursor phase of platy morphology. Candidate precursor phases are discussed below, which are similar in chemical composition and have polysomatically related structures.

\section{Experimental}

\section{Electron microprobe analyses}

Quantitative wavelength-dispersive electron microprobe analyses were carried out on crystals of HKE$3 C$ and HKE-6R, using a Cameca SX100 electron microprobe at the Natural History Museum, London. The operating conditions were: $10 \mathrm{kV}$ accelerating potential, $4 \mathrm{nA}$ probe current and a $30 \mu \mathrm{m}$ beam diameter. Elements detected were $\mathrm{Na}$, $\mathrm{Al}, \mathrm{K}, \mathrm{Ca}, \mathrm{Ti}, \mathrm{Fe}, \mathrm{As}, \mathrm{Ba}$ and W. Fluorine, $\mathrm{Mg}, \mathrm{Si}, \mathrm{P}$, $\mathrm{Cl}, \mathrm{Mn}$ and $\mathrm{Sr}$ were sought, but were below the detection limit. The relevant standards used were: jadeite (Na), cordierite (Al), $\mathrm{KBr}(\mathrm{K})$, wollastonite

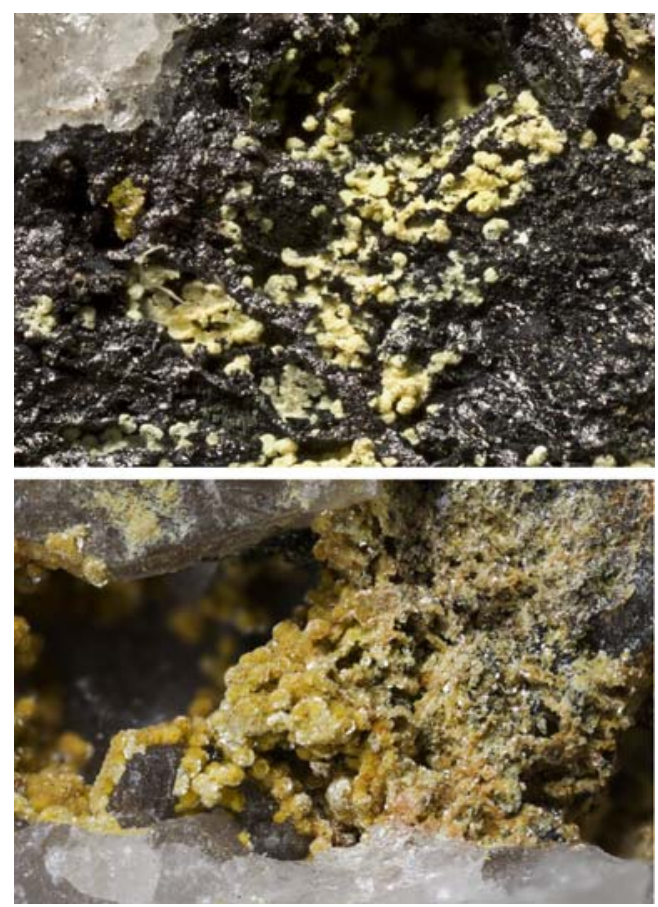

FIg. 1. HKE-3C (top) (BM 2008,56) and HKE-6R (bottom) (BM2006,118) with wolframite and quartz. Field of view $\sim 8 \mathrm{~mm}$ across.
$(\mathrm{Ca})$, rutile $(\mathrm{Ti})$, fayalite $(\mathrm{Fe})$, gallium arsenide (As), barite (Ba) and tungsten metal (W).

\section{$X$-ray diffraction data collection}

The single-crystal study was carried out using a Bruker X8 ApexII single-crystal diffractometer at the Department of Chemistry, University of British Columbia (Table 2). Small fragments of HKE-3C (BM 2008,56) and HKE-6R (BM 2006,56) were used for collection of intensity data at $293 \mathrm{~K}$. The data were processed with the Bruker Apex program suite (Bruker, 2003), with data reduction using the SAINT program and absorption correction by the multi-scan method using SADABS (Bruker, 2003).

The structure of HKE-3C was solved in space group $F d \overline{3} m$ (No. 227) by direct methods using SHELXS-97 and subsequent difference Fourier syntheses followed by full-matrix least-squares refinement on $F^{2}$ using SHELXL-97 (Sheldrick, 2008). The initial location of the framework ions W1, O1 and $\mathrm{O} 2$ were easily located. The Na1 site was located by subsequent inspection of the difference-Fourier maps. Following placement of the atoms and anisotropic treatment, the occupancy of the $\mathrm{Na}$ atom and refinement of electron count at the $\mathrm{W}$ site were performed. We were unable however, to locate the $\mathrm{H}$ associated with the partially occupied $\mathrm{H}_{2} \mathrm{O}$ molecule. The final refinement converged to $R_{1}=0.0130$ for 121 reflections with $F_{o}>4 \sigma(F)$ and 0.0136 for all 126 reflections.

The structure of HKE- $6 R$ was solved in space group $R \overline{3}$ (No. 167) using the same methods as described above. W1 -3 and $\mathrm{O} 1-4$ were first refined anisotropically, followed by the addition of $\mathrm{Na}$ and water molecules located via inspection of the differenceFourier maps. Iron was then refined on all $\mathrm{W}$ sites and the $\mathrm{Na}$ occupancy then was refined. Lastly, all atoms were refined anisotropically. The final refinement for HKE- $6 R$ converged to $R_{1}=0.0196$ for 596 reflections with $F_{o}>4 \sigma(F)$ and 0.0522 for all 1314 reflections. The details of the structure refinement for HKE-3 $C$ and HKE-6 $R$ are provided in Table 2. The refined atomic coordinates, site occupancies and displacement parameters are given in Table 3 and polyhedral bond distances in Table 4.

\section{Results}

\section{Chemical analyses and recalculation}

The crystal structure analyses (below) confirmed that both phases had an octahedral framework 
TABLE 1. Electron microprobe analyses of HKE-3C and HKE-6R.

\begin{tabular}{|c|c|c|c|c|c|c|}
\hline & $\begin{array}{l}\text { HKE-3 } \\
n=15\end{array}$ & & & $\begin{array}{l}\text { HKE- } 6 R \\
n=7\end{array}$ & & \\
\hline wt. $\%$ & Mean & Standard deviation & Range & Mean & Standard deviation & Range \\
\hline $\mathrm{WO}_{3}$ & 77.49 & 0.86 & $76.48-79.37$ & 70.15 & 1.85 & $68.08-72.89$ \\
\hline $\mathrm{As}_{2} \mathrm{O}_{5}$ & 0.15 & 0.04 & $0-0.18$ & 0.12 & 0.05 & $0.08-0.18$ \\
\hline $\mathrm{TiO}_{2}$ & n.d. & - & n.d. & 0.06 & 0.08 & $0-0.18$ \\
\hline $\mathrm{Fe}_{2} \mathrm{O}_{3}$ & 5.83 & 0.29 & $5.27-6.33$ & 8.17 & 0.63 & $6.89-8.75$ \\
\hline $\mathrm{Al}_{2} \mathrm{O}_{3}$ & 2.41 & 0.20 & $2.15-2.85$ & 0.97 & 0.42 & $0.36-1.74$ \\
\hline $\mathrm{CaO}$ & 0.49 & 0.06 & $0.42-0.57$ & 0.58 & 0.23 & $0.27-0.84$ \\
\hline $\mathrm{BaO}$ & 0.10 & 0.02 & $0.06-0.16$ & 0.09 & 0.03 & $0.06-0.15$ \\
\hline $\mathrm{K}_{2} \mathrm{O}$ & 0.22 & 0.02 & $0.17-0.25$ & 0.31 & 0.06 & $0.19-0.37$ \\
\hline $\mathrm{Na}_{2} \mathrm{O}$ & 1.97 & 0.36 & $1.24-2.67$ & 1.57 & 0.27 & $1.25-1.89$ \\
\hline $\mathrm{H}_{2} \mathrm{O}^{*}$ & 7.40 & 0.11 & $7.14-7.60$ & 8.82 & 0.39 & $8.25-9.54$ \\
\hline Total & 96.08 & 0.59 & $95.34-97.16$ & 90.85 & 1.74 & $88.57-92.98$ \\
\hline \multicolumn{7}{|c|}{$\begin{array}{l}\text { Numbers of ions, recalculated to } 2 B \text { sites and } 6 X \text { sites } \\
A \text { sites }\end{array}$} \\
\hline $\mathrm{K}^{+}$ & 0.02 & 0.002 & 0.02 & 0.03 & 0.01 & $0.02-0.04$ \\
\hline $\mathrm{Na}^{+}$ & 0.28 & 0.05 & $0.17-0.38$ & 0.24 & 0.04 & $0.19-0.29$ \\
\hline $\mathrm{Ba}^{2+}$ & 0.003 & 0.001 & $0.002-0.004$ & 0.003 & 0.001 & $0.002-0.004$ \\
\hline $\mathrm{Ca}^{2+}$ & 0.04 & 0.004 & $0.03-0.05$ & 0.04 & 0.02 & $0.02-0.07$ \\
\hline $\mathrm{H}_{2} \mathrm{O}^{*}$ & 0.20 & - & - & 0.63 & - & - \\
\hline$\square_{B \text { sites }}$ & 1.46 & 0.05 & $1.37-1.55$ & 1.06 & 0.03 & $1.01-1.09$ \\
\hline $\mathrm{W}^{6+}$ & 1.47 & 0.02 & $1.45-1.51$ & 1.42 & 0.04 & $1.37-1.49$ \\
\hline $\mathrm{Fe}^{3+}$ & 0.32 & 0.02 & $0.29-0.35$ & 0.49 & 0.04 & $0.41-0.53$ \\
\hline $\mathrm{Al}^{3+}$ & 0.21 & 0.02 & $0.19-0.25$ & 0.08 & 0.04 & $0.03-0.15$ \\
\hline $\mathrm{Ti}^{4+}$ & - & - & - & 0.004 & 0.005 & $0-0.011$ \\
\hline $\begin{array}{l}\mathrm{As}^{5+} \\
X \text { sites }\end{array}$ & 0.006 & 0.002 & $0-0.007$ & 0.005 & 0.002 & $0.003-0.007$ \\
\hline $\mathrm{O}^{2-}$ & 4.79 & - & $4.72-4.91$ & 4.65 & - & $4.49-4.92$ \\
\hline $\begin{array}{l}\mathrm{OH}^{-*} \\
Y \text { sites }\end{array}$ & 1.21 & 0.05 & $1.09-1.28$ & 1.35 & 0.14 & $1.08-1.51$ \\
\hline $\mathrm{H}_{2} \mathrm{O}^{*}$ & 1 & - & - & 1 & - & - \\
\hline
\end{tabular}

*Water content calculated as explained in the text.

structure with the pyrochlore topology (Atencio et al., 2010). Relative to the ideal pyrochlore stoichiometry $A_{2} B_{2} X_{6} Y$, the refinements showed full occupancy of $B$ sites by cations, but very low $A$ occupancy. For the $6 R$ phase, the refinement also showed oxygen atoms ordered in some of the $A$ sites and in all of the $Y$ sites where bond-valence sums to cations would be very small, implying that these were actually $\mathrm{H}_{2} \mathrm{O}$.

Given the low occupancy of $A$ cation sites but full occupancy of framework $B$ cation sites in the pyrochlore structure determined by the structure refinement, analyses were recalculated to two $B$ cations $(\mathrm{W}+\mathrm{Fe}+\mathrm{Al}+\mathrm{Ti}+\mathrm{As})$. All Fe was assumed to be trivalent and all As pentavalent. $\mathrm{Na}+\mathrm{K}+\mathrm{Ca}+\mathrm{Ba}$ were assumed to be confined to $A$ sites. Based on the structure refinements (below), water content was estimated as follows.

For the $3 C$ phase: Full occupancy of $Y$ sites by $\mathrm{H}_{2} \mathrm{O}$ was assumed, plus $0.2 \mathrm{H}_{2} \mathrm{O}$ in $A$ sites. Substitution of some $\mathrm{OH}^{-}$for $\mathrm{O}^{2-}$ in the $X$ sites was required, to achieve electroneutrality.

For the $6 R$ phase: Full occupancy of $Y$ sites by $\mathrm{H}_{2} \mathrm{O}$ was assumed, as was $0.61^{A}\left(\mathrm{H}_{2} \mathrm{O}\right)$ per formula unit, corresponding to $48-50 \%$ occupancy of $5 / 8$ of the $A$ sites by $\mathrm{H}_{2} \mathrm{O}$, and substitution of some $\mathrm{OH}^{-}$ for $\mathrm{O}^{2-}$ in $X$ sites for electroneutrality.

The occupation models are discussed in more detail below. Note that alternative distributions of 
TABLE 2. Data collection and structure refinement details for HKE-3C and HKE-6R.

\begin{tabular}{|c|c|c|}
\hline & HKE-3C & HKE-6R \\
\hline Diffractometer & \multicolumn{2}{|c|}{ Bruker X8 ApexII } \\
\hline $\mathrm{X}$-ray radiation & \multicolumn{2}{|c|}{$0.71073 \AA$} \\
\hline Temperature & \multirow{2}{*}{\multicolumn{2}{|c|}{$\begin{array}{c}298(2) \mathrm{K} \\
\left(\square, \mathrm{Na}, \mathrm{H}_{2} \mathrm{O}\right)_{2}\left(\mathrm{~W}, \mathrm{Fe}^{3+}, \mathrm{Al}\right)_{2}(\mathrm{O} \\
\mathrm{OH})_{6} \cdot \mathrm{H}_{2} \mathrm{O}\end{array}$}} \\
\hline Structural formula & & \\
\hline Space group & $F d \overline{3} m$ & $R \overline{3}$ \\
\hline $\begin{array}{l}\text { Unit-cell } \\
\text { dimensions }\end{array}$ & $a=10.3065(3) \AA$ & $\begin{array}{c}a=7.2882(2) \AA \\
c=35.7056(14) \AA\end{array}$ \\
\hline$V$ & $1094.80(6) \AA^{3}$ & $1642.51(9) \AA^{3}$ \\
\hline$Z$ & 16 & 9 \\
\hline $\begin{array}{l}\text { Absorption } \\
\text { coefficient }\end{array}$ & $32.659 \mathrm{~mm}^{-1}$ & $30.237 \mathrm{~mm}^{-1}$ \\
\hline$F(000)$ & 1416 & 2170 \\
\hline$\circ$ range & 3.42 to $33.11^{\circ}$ & 1.71 to $33.11^{\circ}$ \\
\hline Index ranges & $\begin{array}{l}-13 \leq h \leq 15 \\
-15 \leq k \leq 14 \\
-14 \leq l \leq 14\end{array}$ & $\begin{array}{l}-10 \leq h \leq 11 \\
-11 \leq k \leq 10 \\
-53 \leq l \leq 53\end{array}$ \\
\hline $\begin{array}{l}\text { Reflections } \\
\text { collected/ } \\
\text { unique }\end{array}$ & $\begin{array}{c}5304 / 126\left[R_{\mathrm{int}}=\right. \\
0.0197]\end{array}$ & $\begin{array}{l}11856 / 1314\left[R_{\mathrm{int}}\right. \\
\quad=0.0233]\end{array}$ \\
\hline $\begin{array}{l}\text { Reflections with } \\
F_{\mathrm{o}}>4 \sigma(F)\end{array}$ & 121 & 596 \\
\hline $\begin{array}{l}\text { Refinement } \\
\text { method }\end{array}$ & $\begin{array}{l}\text { Full-matrix least- } \\
\text { squares on } F^{2}\end{array}$ & $\begin{array}{l}\text { Full-matrix least- } \\
\text { squares on } F^{2}\end{array}$ \\
\hline Parameters refined & 14 & 78 \\
\hline $\begin{array}{l}\text { Final } R \text { indices } \\
\qquad\left[F_{\mathrm{o}}>4 \sigma(F)\right]\end{array}$ & $\begin{array}{c}R_{1}=0.0130 \\
\mathrm{w} R_{2}=0.0316\end{array}$ & $\begin{array}{c}R_{1}=0.0196 \\
\mathrm{w} R_{2}=0.0343\end{array}$ \\
\hline$R$ indices (all data) & $\begin{array}{c}R_{1}=0.0136 \\
\mathrm{w} R_{2}=0.0318\end{array}$ & $\begin{array}{c}R_{1}=0.0521, \\
\mathrm{w} R_{2}=0.0403\end{array}$ \\
\hline $\begin{array}{l}\text { Extinction } \\
\text { coefficient }\end{array}$ & $0.00018(5)$ & $0.000110(12)$ \\
\hline Goof & 1.312 & 1.115 \\
\hline
\end{tabular}

the protons are possible, but these require either hydronium ions to be present in $A$ or $Y$ sites, or even more protonation of $X$ anions.

Analyses are shown in Table 1, after rejection of two points for the $3 C$ phase and one for the $6 R$ phase which gave low totals, low $\mathrm{W}$ contents and anomalously high $\mathrm{Al}$ contents, suggesting contamination by $\mathrm{Al}$ oxyhydroxides. Totals for the remaining analyses are still low (95-97\% for the $3 C$ phase and $88-93 \%$ for $6 R$ ), as would be expected for highly hydrous materials that dehydrate under the electron beam but cannot undergo structure collapse and densification.

The data of Table 1 include $\mathrm{H}$ content calculated as described above, and $\mathrm{O}$ content calculated from cation valences, and apportioned between oxide components. The average formulae, expressed in terms of the pyrochlore-type $A_{2} B_{2} X_{6} Y$ formula unit, are very similar, respectively:

$\left(\mathrm{Na}_{0.28} \mathrm{Ca}_{0.04} \mathrm{~K}_{0.02}\left(\mathrm{H}_{2} \mathrm{O}\right)_{0.20} \square_{1.46}\right)_{\sum 2.00}$ $\left(\mathrm{W}_{1.47} \mathrm{Fe}_{0.32}^{3+} \mathrm{Al}_{0.21} \mathrm{As}_{0.01}^{5+}\right)_{\sum 2.00}\left[\mathrm{O}_{4.79}(\mathrm{OH})_{1.21}\right]_{\sum 6.00}$ $\cdot\left(\mathrm{H}_{2} \mathrm{O}\right)(3 \mathrm{C}$ phase $)$ and $\left(\mathrm{Na}_{0.24} \mathrm{Ca}_{0.04} \mathrm{~K}_{0.03}\left(\mathrm{H}_{2} \mathrm{O}\right)_{0.63}\right.$ $\left.\square_{1.06}\right)_{\sum 2.00}\left(\mathrm{~W}_{1.42} \mathrm{Fe}_{0.49}^{3+} \mathrm{Al}_{0.08} \mathrm{As}_{0.01}^{5+}\right)_{\sum 2.00}\left[\mathrm{O}_{4.65}\right.$ $\left.(\mathrm{OH})_{1.35}\right]_{\sum 6.00} \cdot\left(\mathrm{H}_{2} \mathrm{O}\right)$ (6R phase). Both of these compositions can be simplified as $\left(\square, \mathrm{Na}, \mathrm{H}_{2} \mathrm{O}\right)_{2}(\mathrm{~W}$, $\left.\mathrm{Fe}^{3+}, \mathrm{Al}\right)_{2}(\mathrm{O}, \mathrm{OH})_{6} \cdot \mathrm{H}_{2} \mathrm{O}$, which corresponds to the name hydrokenoelsmoreite in the nomenclature scheme of Atencio et al. (2010). More quantitatively, the formulae can be expressed, neglecting very minor substituents, as $\left(A_{2-x}^{0} \mathrm{Na}_{x}\right)\left(\mathrm{W}_{2-y} B^{3+}{ }_{y}\right)$ $\left(\mathrm{O}_{6-z}(\mathrm{OH})_{z}\right) \cdot \mathrm{H}_{2} \mathrm{O}$, where $x=0.17-0.29, y=0.49-$ 0.63 and $z=3 y-x$. The major differences between the compositions are that $A^{0}$ corresponds to vacancies except for $\sim 0.20\left(\mathrm{H}_{2} \mathrm{O}\right)$ for the $3 C$ phase and $\sim 0.63\left(\mathrm{H}_{2} \mathrm{O}\right)$ for the $6 R$ phase, while $B^{3+}$ has $\mathrm{Al} /(\mathrm{Al}+\mathrm{Fe})=0.35-0.45$ for the $3 C$ phase but only $0.06-0.24$ for the $6 R$ phase.

\section{Crystal structure}

The HKE-3C phase crystallizes in space group $F d \overline{3} m$, with $a=10.3065(3) \AA$ and $Z=8\left[A_{2} B_{2} X_{6} Y\right]$, which is typical for a material with the normal pyrochlore structure (Atencio et al., 2010) and is consistent with that reported for 'elsmoreite' (Williams et al., 2005) and synthetic $\mathrm{WO}_{3} \cdot 0.5 \mathrm{H}_{2} \mathrm{O}$ (Günter et al., 1989). A unit cell of the structure is shown in Fig. $2 a$.

In the structure of HKE-3C, the $Y$ site is fully occupied by $\mathrm{O}$ of a water molecule, while the scattering factors in the $A$ and $B$ sites correspond to 3.1(2) and 57.4(7) electrons, respectively. The $A$-site scattering corresponds to $0.28(2) \mathrm{Na}, 0.39(3) \mathrm{O}$ or a mixture of the two, but the chemical analysis (above) is consistent with about a $50: 50 \mathrm{mix}$ of $\mathrm{Na}$ and $\mathrm{H}_{2} \mathrm{O}$ end-members. The $B$ site was refined as partiallyoccupied $\mathrm{W}$, but if there are taken to be no vacancies on $B$ sites and the ratio $\mathrm{Al}: \mathrm{Fe}$ is taken to be about 0.4:0.6, consistent with analyses, then the $B$-site scattering corresponds to $\left(\mathrm{W}_{0.688} \mathrm{Fe}_{0.187} \mathrm{Al}_{0.125}\right)$. Thus, the structure corresponds to the composition: ${ }^{A}\left[\square_{1.44} \mathrm{Na}_{0.28}\left(\mathrm{H}_{2} \mathrm{O}\right)_{0.20}\right]_{\sum 2.00}{ }^{B}\left[\mathrm{~W}_{1.38} \mathrm{Fe}_{0.37}^{3+} \mathrm{Al}_{0.25}\right]_{\sum 2.00}$ ${ }^{X}\left[\mathrm{O}_{4.42}(\mathrm{OH})_{1.58}\right]_{\sum 6.00}\left[\mathrm{H}_{2} \mathrm{O}\right]_{\sum 1.00}$, which is within the range of simplified compositions derived above. The $3 C$ structure was reported by Ercit and Robinson (1994) for a refinement of 'ferritungstite' which would now also be classified as hydrokenoelsmoreite-3C, with structural formula ${ }^{A}\left[\square_{1.33}\left(\mathrm{H}_{2} \mathrm{O}\right)_{0.59} \mathrm{Ca}_{0.06} \mathrm{Na}_{0.02}\right]_{\sum 2.00}{ }^{B}\left[\mathrm{~W}_{1.46} \mathrm{Fe}_{0.54}^{3+}\right]_{\sum 2.00}$ ${ }^{X}\left[\mathrm{O}_{4.70}(\mathrm{OH})_{1.30}\right]_{\sum^{6.00}}{ }^{Y}\left[\left(\mathrm{H}_{2} \mathrm{O}\right)_{0.80} \mathrm{~K}_{0.20}\right]_{\Sigma 1.00}$. Note that 
TABLE 3. Atom coordinates and displacement parameters $\left(\AA^{2}\right)$ for HKE-3C and HKE- $6 R$.

\begin{tabular}{|c|c|c|c|c|c|c|c|c|c|c|c|}
\hline & $x / a$ & $y / b$ & $z / c$ & Occ. & $U_{\mathrm{eq}}$ & $U^{11}$ & $U^{22}$ & $U^{33}$ & $U^{23}$ & $U^{13}$ & $U^{12}$ \\
\hline \multicolumn{12}{|c|}{ HKE-3C } \\
\hline W1 & $1 / 2$ & $1 / 2$ & 0 & $0.776(10)$ & $0.02283(18)$ & $0.02283(18)$ & $0.02283(18)$ & $0.02283(18)$ & $-0.00518(7)$ & $-0.00518(7)$ & $-0.00518(7)$ \\
\hline $\mathrm{Na} 1$ & $1 / 2$ & $1 / 4$ & $1 / 4$ & $0.28(2)$ & $0.024(4)$ & $0.024(4)$ & $0.024(4)$ & $0.024(4)$ & $-0.004(2)$ & $0.004(2)$ & $0.004(2)$ \\
\hline $\mathrm{O} 1$ & $0.5628(3)$ & $3 / 8$ & $-1 / 8$ & 1 & $0.0211(9)$ & $0.0204(16)$ & $0.0214(11)$ & $0.0214(11)$ & $-0.0046(11)$ & 0 & 0 \\
\hline $\mathrm{O} 2$ & $5 / 8$ & $1 / 8$ & $1 / 8$ & 1 & $0.051(3)$ & $0.051(3)$ & $0.051(3)$ & $0.051(3)$ & 0 & 0 & 0 \\
\hline \multicolumn{12}{|c|}{ HKE-6R } \\
\hline W1 & 1 & 1 & 0 & $0.684(12)$ & $0.0230(7)$ & $0.0278(10)$ & $0.0278(10)$ & $0.0134(10)$ & 0 & 0 & $0.0139(5)$ \\
\hline $\mathrm{Fe} 1$ & 1 & 1 & 0 & $0.316(12)$ & $0.0230(7)$ & $0.0278(10)$ & $0.0278(10)$ & $0.0134(10)$ & 0 & 0 & $0.0139(5)$ \\
\hline W2 & $1 / 3$ & $2 / 3$ & 0.1667 & $0.677(12)$ & $0.0220(7)$ & $0.0272(9)$ & $0.0272(9)$ & $0.0118(10)$ & 0 & 0 & $0.0136(5)$ \\
\hline $\mathrm{Fe} 2$ & $1 / 3$ & $2 / 3$ & 0.1667 & $0.323(12)$ & $0.0220(7)$ & $0.0272(9)$ & $0.0272(9)$ & $0.0118(10)$ & 0 & 0 & $0.0136(5)$ \\
\hline W3 & $0.66670(18)$ & $0.8333(2)$ & $0.08327(3)$ & $0.679(6)$ & $0.02261(9)$ & $0.01384(11)$ & $0.02436(13)$ & $0.02609(13)$ & $0.00243(8)$ & $0.00488(7)$ & $0.00691(8)$ \\
\hline $\mathrm{Fe} 3$ & $0.66670(18)$ & $0.8333(2)$ & $0.08327(3)$ & $0.321(6)$ & $0.02261(9)$ & $0.01384(11)$ & $0.02436(13)$ & $0.02609(13)$ & $0.00243(8)$ & $0.00488(7)$ & $0.00691(8)$ \\
\hline $\mathrm{Na} 4$ & $1 / 2$ & 1 & 0 & $0.33(2)$ & $0.025(5)$ & $0.021(7)$ & $0.056(10)$ & $0.010(6)$ & $0.014(5)$ & $0.010(5)$ & $0.028(7)$ \\
\hline $\mathrm{O} 1$ & $1.1254(17)$ & $1.2501(15)$ & $0.03119(19)$ & 1 & $0.024(2)$ & $0.027(5)$ & $0.024(5)$ & $0.016(4)$ & $-0.009(3)$ & $-0.010(3)$ & $0.010(4)$ \\
\hline $\mathrm{O} 2$ & $0.4581(14)$ & $0.9169(13)$ & $0.07309(18)$ & 1 & $0.019(2)$ & $0.018(4)$ & $0.022(4)$ & $0.017(3)$ & $-0.008(3)$ & $-0.003(3)$ & $0.010(4)$ \\
\hline $\mathrm{O} 3$ & $0.8749(15)$ & $0.7501(14)$ & $0.0940(2)$ & 1 & $0.026(2)$ & $0.019(5)$ & $0.027(5)$ & $0.037(4)$ & $0.016(3)$ & $0.007(4)$ & $0.015(4)$ \\
\hline $\mathrm{O} 4$ & $0.5832(13)$ & $0.7915(16)$ & $0.1354(2)$ & 1 & $0.021(2)$ & $0.016(5)$ & $0.021(5)$ & $0.022(4)$ & $0.003(3)$ & $-0.006(3)$ & $0.006(4)$ \\
\hline WA1 & $2 / 3$ & 1.3333 & $0.0214(6)$ & 1 & $0.052(6)$ & $0.054(11)$ & $0.054(11)$ & $0.048(12)$ & 0 & 0 & $0.027(5)$ \\
\hline WA2 & $2 / 3$ & 1.3333 & $0.1462(6)$ & 1 & $0.050(6)$ & $0.047(9)$ & $0.047(9)$ & $0.054(13)$ & 0 & 0 & $0.024(5)$ \\
\hline WA3 & $2 / 3$ & 1.3333 & $0.0828(13)$ & $0.50(3)$ & $0.023(3)$ & $0.020(4)$ & $0.020(4)$ & $0.030(6)$ & 0 & 0 & $0.0100(18)$ \\
\hline WA4 & 0.8333 & 1.1667 & 0.1667 & $0.52(4)$ & $0.038(7)$ & $0.047(13)$ & $0.046(12)$ & $0.051(13)$ & $0.026(9)$ & $0.008(9)$ & $0.046(11)$ \\
\hline
\end{tabular}


TABLE 4 Selected bond distances $(\AA)$ in HKE-3 $C$ and HKE- $6 R$.

\begin{tabular}{llll}
\hline HKE-3C & & & \\
W1 & $-\mathrm{O} 1$ & $1.9335(11)$ & $\times 6$ \\
& & & \\
$\mathrm{Na} 1$ & $-\mathrm{O} 2$ & $2.2314(11)$ & $\times 2$ \\
$\mathrm{Na} 1$ & $-\mathrm{O} 1$ & $2.654(2)$ & $\times 6$ \\
$<\mathrm{Na}-\mathrm{O}>$ & & 2.548 & \\
$\mathrm{HKE}-6 R$ & & & \\
$\mathrm{~W} 1$ & $-\mathrm{O} 1$ & $1.932(8)$ & $\times 6$ \\
$\mathrm{~W} 2$ & $-\mathrm{O} 4$ & $1.932(9)$ & $\times 6$ \\
$\mathrm{~W} 3$ & $-\mathrm{O} 2$ & $1.929(10)$ & \\
$\mathrm{W} 3$ & $-\mathrm{O} 1$ & $1.932(7)$ & \\
$\mathrm{W} 3$ & $-\mathrm{O} 3$ & $1.933(10)$ & \\
$\mathrm{W} 3$ & $-\mathrm{O} 2$ & $1.934(10)$ & \\
$\mathrm{W} 3$ & $-\mathrm{O} 4$ & $1.935(8)$ & \\
$\mathrm{W} 3$ & $-\mathrm{O} 3$ & $1.936(10)$ & \\
$<\mathrm{W}-\mathrm{O}>$ & & 1.933 & \\
& & & \\
$\mathrm{Na} 4$ & $-\mathrm{WA} 1$ & $2.239(8)$ & $\times 2$ \\
$\mathrm{Na} 4$ & $-\mathrm{O} 1$ & $2.653(10)$ & $\times 2$ \\
$\mathrm{Na} 4$ & $-\mathrm{O} 1$ & $2.656(10)$ & $\times 2$ \\
$\mathrm{Na} 4$ & $-\mathrm{O} 2$ & $2.662(7)$ & $\times 2$ \\
$<\mathrm{Na}-\mathrm{O}>$ & & 2.553 & \\
& & & \\
\hline
\end{tabular}

relative to the $3 \mathrm{C}$ mineral of the present study, their composition has more $\mathrm{H}_{2} \mathrm{O}$ and less $\mathrm{Na}$ in $A$ sites, no $\mathrm{Al}$ in $B$, and some $\mathrm{K}$ playing an inverse pyrochlore' role in the $Y$ site (see below).

If the cubic pyrochlore structure is referred to an $R$ lattice with the hexagonal axial setting, a cell is obtained with $a_{R}=a_{\text {cub }} / \sqrt{ } 2 \sim 7.3 \AA$, $c_{R}=a_{\mathrm{cub}} \times \sqrt{ } 3 \sim 17.8 \AA$ and $Z=6 \quad\left[A_{2} B_{2} X_{6} Y\right]$ (Fig. 2b). Because of the rhombohedral lattice centring, this cell consists of a stacking of three translationally equivalent layers $\|(003)$, hence the Ramsdell notation ' $3 C$ ' for the cubic structure. The HKE- $6 R$ phase has $a=7.2882(2) \AA$ and $c=$ $35.7056(14)=2 \times 17.8528 \AA$, so the periodicity along the unique threefold axis is doubled relative to the cubic structure. In space group $R \overline{3}$, there is considerable splitting of the sites of the cubic pyrochlore aristotype: crystallographically, the $6 R$ structure can be represented as $(A 1)_{3}(A 2)_{2}(A 3)_{3}$ $(B 1)_{1}(B 2)_{1}(B 3)_{6}(X 1)_{6}(X 2)_{6}(X 3)_{6}(X 4)_{6}(Y 1)_{2}(Y 2)_{2}$.

Site occupancies were as follows.

$$
\begin{aligned}
& A 1=\mathrm{Na} 4=0.33(2) \mathrm{Na} \\
& A 2=\mathrm{WA} 3=0.50(3) \mathrm{O}\left(\equiv \mathrm{H}_{2} \mathrm{O}\right) . \\
& A 3=\mathrm{WA} 4=0.48(4) \mathrm{O}\left(\equiv \mathrm{H}_{2} \mathrm{O}\right) . \\
& B 1=0.683(11) \mathrm{W}+0.317(11) \mathrm{Fe} \\
& B 2=0.678(11) \mathrm{W}+0.312(11) \mathrm{Fe}
\end{aligned}
$$

$B 3=0.679(7) \mathrm{W}+0.321(7) \mathrm{Fe}$

$X 1-X 4=1.00 \mathrm{O}$ (some is $\mathrm{OH}$, for charge balance).

$Y 1-Y 2=$ WA1-WA2 $=1.00 \mathrm{O}\left(\equiv \mathrm{H}_{2} \mathrm{O}\right)$.

There is clearly negligible long-range order of $\mathrm{W}$ and trivalent cations in $B$ sites. Although the $B$ site occupants were refined as mixtures of $\mathrm{W}+\mathrm{Fe}$, the electron count of 58.6(9) can be achieved with either $\mathrm{W}_{0.68} \mathrm{Fe}_{0.32}$ or, if the light atom is taken to be $\mathrm{Fe}+\mathrm{Al}$ in an 85:15 ratio, $\mathrm{W}_{0.69} \mathrm{Fe}_{0.26} \mathrm{Al}_{0.05}$, with very little change to the $\mathrm{W}$ content. As there is no differential occupancy of $B, X$ or $Y$ sites, the doubling of periodicity along the $\mathbf{c}$ direction must be due to the differing occupancies of the three types of $A$ site (Fig. 2c). There is very little difference in scattering factor between these sites $(0.33 \mathrm{Na}, 0.50 \mathrm{O}$ and $0.48 \mathrm{O}$ correspond to 3.6, 4.0 and $3.8 e^{-}$respectively). Similarly, all positions have similar local environments, being surrounded by $6 \times \mathrm{O}$ at $2.63-2.67 \AA$ and $2 \times \mathrm{O}$ at $2.18-2.24 \AA$. Allocation of $\mathrm{Na}$ exclusively to either $A 1$ or $A 3$ allows the total $\mathrm{Na}$ content to be compatible with both the refinement and chemical analyses. Here, $\mathrm{Na}$ is placed in $A 1$ sites, while $A 2$ and $A 3$ are both $\sim 50 \%$ occupied by $\mathrm{H}_{2} \mathrm{O}$, leading to the assumption of $5 / 8\left(\mathrm{H}_{2} \mathrm{O}\right)$ in the $A$ sites per pyrochlore formula unit in the compositions above. The occupancies above, if referred to a pyrochlore-like formula unit, correspond to: ${ }^{A}\left[\square_{1.14}\left(\mathrm{H}_{2} \mathrm{O}\right)_{0.61} \mathrm{Na}_{0.25}\right]_{\sum 2.00}$ ${ }^{B}\left[\mathrm{~W}_{1.38} \mathrm{Fe}_{0.52}^{3+} \mathrm{Al}_{0.10}\right]_{\sum 2.00}{ }^{X}\left[\mathrm{O}_{4.39}(\mathrm{OH})_{1.61}\right]_{\sum 6.00}$ ${ }^{Y}\left[\mathrm{H}_{2} \mathrm{O}\right]_{\sum 1.00 \text {, which again is close to the analysed }}$ composition.

Using the hexagonal unit-cell metric for the pyrochlore structure facilitates comparison with polysomatically related structures. The three equivalent layers of the pyrochlore $R$ cell have thickness $17.8 / 3 \approx 6 \AA$. Grey et al. (2006) noted that these structural slabs can connect to each other directly, as they do in the pyrochlore structure, or they can link to slabs with a hexagonal tungsten bronze (HTB) topology and thickness $3.7 \AA$, and that an alternative view of the HTB slab structure was as a local rearrangement of the pyrochlore framework around twin boundaries on the $(001)_{R}$ composition plane. The geometrical compatibility arises because the pyrochlore framework itself already contains HTB-like layers. In all cases, a framework is made through $B X_{6}$ octahedra sharing all corners, so the $B X_{3}$ stoichiometry of the framework is unchanged. Walenta (1984) and Birch et al. (2007) presented descriptions of the related minerals pittongite and phyllotungstite, and showed that their structures correspond to other members of a polysomatic family. If $6 \AA$-wide pyrochlore slabs are 

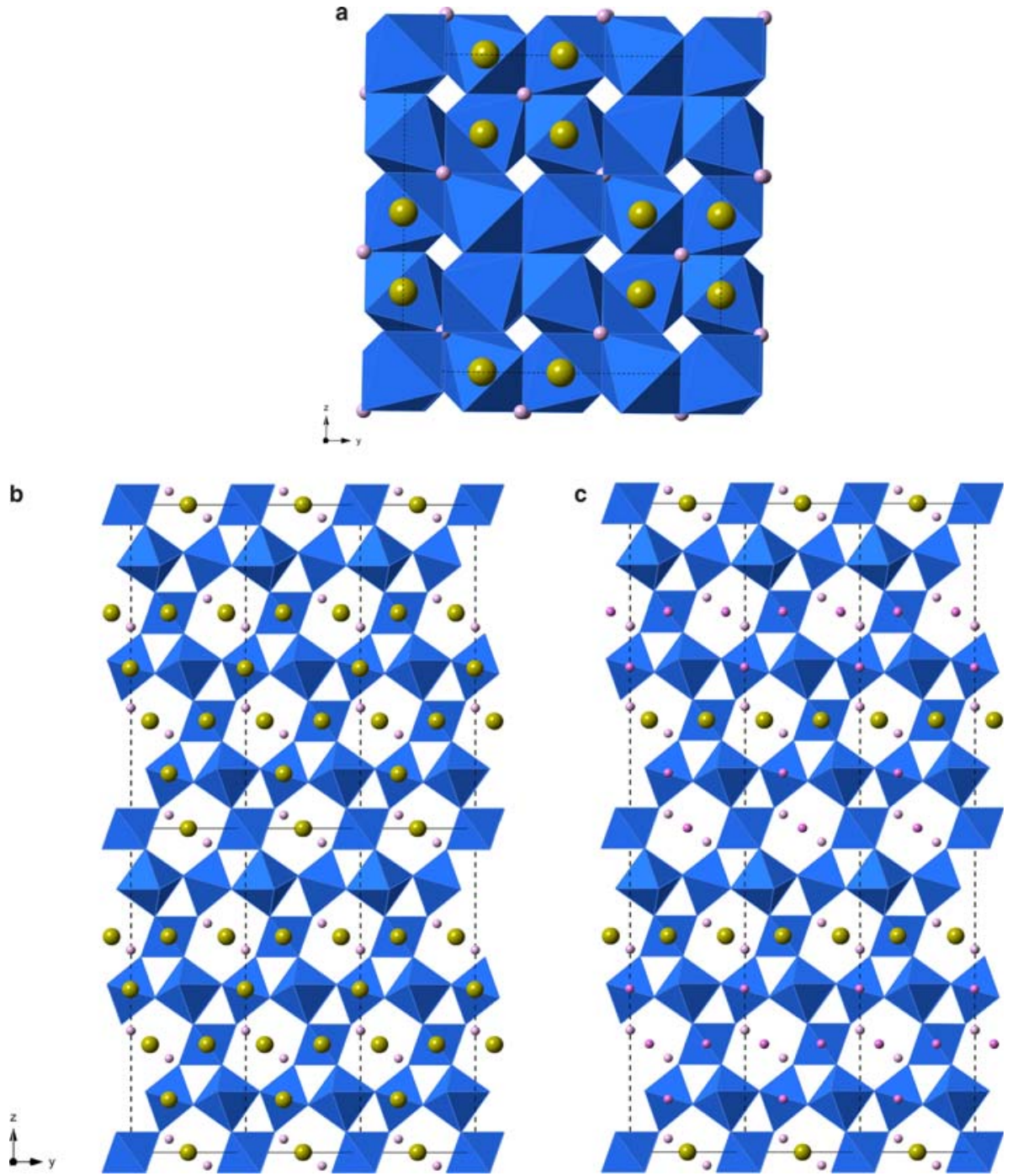

FIG. 2. (a) Crystal structure of HKE-3C viewed down $\mathbf{x}$ in the conventional cubic axial setting. The $B(\mathrm{O}, \mathrm{OH})_{6}$ octahedra ( $B=\mathrm{W}, \mathrm{Fe}$ and $\mathrm{Al}$ ) of the framework are shown in blue, $A$ sites partially occupied by $\mathrm{Na}$ and $\mathrm{H}_{2} \mathrm{O}$ are shown as yellow spheres and $\mathrm{H}_{2} \mathrm{O}$ molecules in $Y$ sites are indicated by pink spheres. (b) The HKE-3C structure in the hexagonal axial setting, viewed down $\mathbf{x}$. A block of $3 \times 2$ unit cells is shown, to aid comparison with the $6 R$ structure. $(c)$ The $6 R$ structure. Note doubled $c$ repeat, and alternation of layers of $A$ sites that contain $\mathrm{Na}$ (yellow spheres) with $A$ sites that contain $\mathrm{H}_{2} \mathrm{O}$ (dark pink spheres).

denoted by $P$ and HTB slabs by $H$, then the translational repeat of the pyrochlore structure is $\langle P>$, phyllotungstite is $\langle P H P H>$ and pittongite $<$ PHPPHPPHPH>. Grey et al. (2007) reported two more polysomes in the $\mathrm{Bi}_{2} \mathrm{O}_{3}-\mathrm{Fe}_{2} \mathrm{O}_{3}-\mathrm{Nb}_{2} \mathrm{O}_{5}$ system, $<P P H>$ and $\angle P P H P H>$. The structure refinement of phyllotungstite by Grey et al. (2013) confirmed the model, but also showed that the $H$ module has a different content of non-framework structural sites from pyrochlore. The crystallographic stoichiometry of the $H$ slab is best regarded as $C A B_{3} X_{9}=$ $C_{0.67} A_{0.67} B_{2} X_{6}$, where $C$ is an 18-coordinated site in a large hexagonal-prismatic cavity, which contain a small proportion of $\mathrm{Cs}$ in the refinement of Grey et al. (2013). As the $C$ site is $<2.1 \AA$ from the two nearest $A$ sites and vice versa, full occupation of both is not 


\section{Pyrochlore}

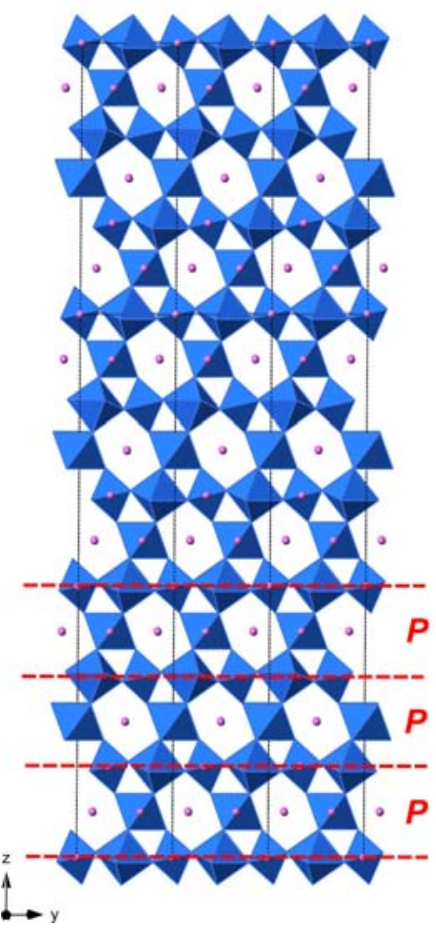

Phyllotungstite

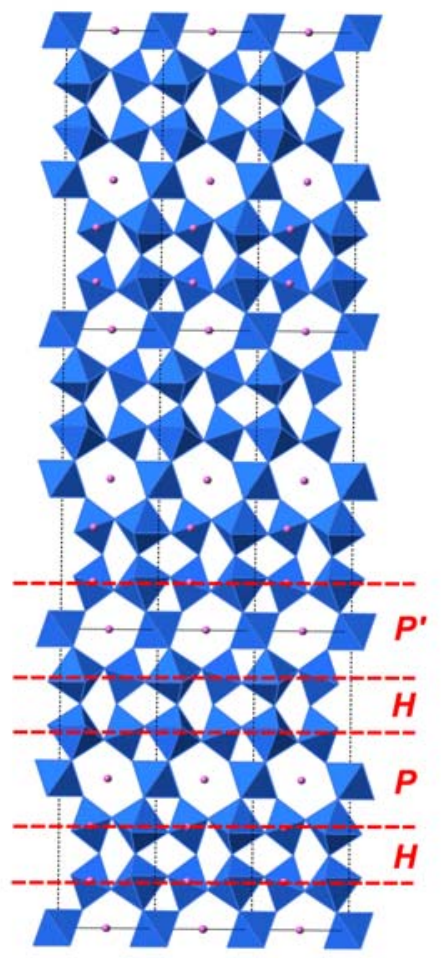

Pittongite

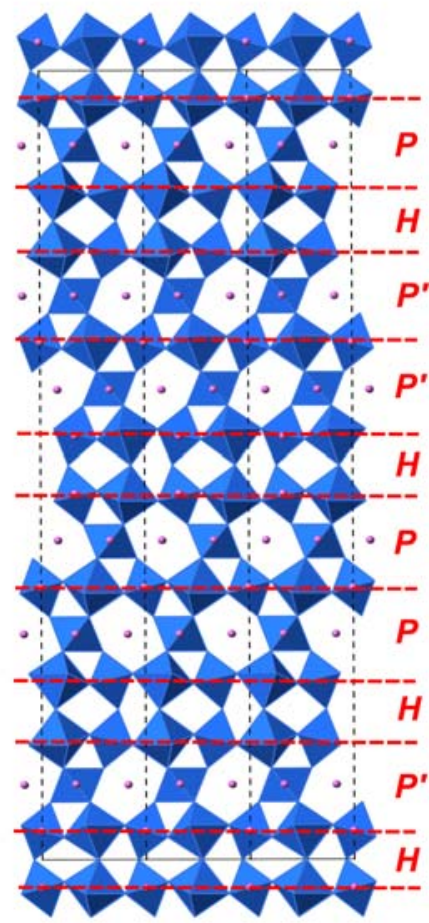

FIG. 3. Pyrochlore and related structures, with axial setting and viewing direction the same as for Figs $2 b$ and $c$. $C$-and $Y$-site atoms are omitted for clarity. $A$ sites are shown as small pink spheres. $6 \AA$-wide pyrochlore slabs are indicated by $P$, or by $P^{\prime}$ if in the alternative twin orientation related by $180^{\circ}$ rotation about $\mathbf{z}$, while $3.7 \AA$-wide HTB slabs are shown as $H$.

possible. The twofold linear coordination of $A$ by $C$ and ability of $C$ to accommodate extremely large cations such as Cs make it in those respects the HTB analogue of the pyrochlore $Y$ site. The $A_{4} B_{4} X_{12} Y_{2}$ stoichiometry of the $6 \AA P$ slab and $A B_{3} X_{9} C$ stoichiometry of the $H$ slab can be combined to give ideal stoichiometries of $A_{5} B_{7} X_{21} Y_{2} C$ for phyllotungstite and $A_{14} B_{18} X_{54} Y_{6} C_{2}=A_{7} B_{9} X_{27} Y_{3} C$ for pittongite, although low occupancy in the $A, C$ and $Y$ sites means that in practice, no difference from the pyrochlore formula would be noticeable.

The compositions derived for the polysomes can be expressed in pyrochlore format for pittongite as: $\left[\mathrm{Na}_{0.44} \mathrm{Ca}_{0.04}\right]_{\sum 0.48}\left[\mathrm{~W}_{1.64} \mathrm{Fe}_{0.32}^{3+} \mathrm{Al}_{0.04}^{3+}\right]_{\sum 2.00}\left[\mathrm{O}_{5.40}\right.$ $\left.\mathrm{OH}_{0.60}\right]_{\sum 6.00}\left[\mathrm{H}_{2} \mathrm{O}\right]_{\sum 0.88}$ (Birch et al., 2007) and for phyllotungstite: $\left[\mathrm{Na}_{0.13} \mathrm{~Pb}_{0.04}\right]_{\sum 0.17}\left[\mathrm{~W}_{1.30} \mathrm{Fe}_{0.70}^{3+}\right]_{\sum 2.00}$ $\left[\mathrm{O}_{4.27} \mathrm{OH}_{1.73}\right]_{\sum 6.00}\left[\mathrm{H}_{2} \mathrm{O}\right]_{\sum 1.48}($ Grey et al., 2006) and $\left[\mathrm{Pb}_{0.29} \mathrm{Ca}_{0.04} \mathrm{Na}_{0.02} \mathrm{~K}_{0.01}\right]_{\sum 0.36}\left[\mathrm{~W}_{1.55} \mathrm{Fe}_{0.45}^{3+}\right]_{\sum 2.00}\left[\mathrm{O}_{5.11}\right.$ $\left.\mathrm{OH}_{0.89}\right]_{\sum 6.00}\left[\left(\mathrm{H}_{2} \mathrm{O}\right)_{0.43} \mathrm{O}_{0.14} \mathrm{Cs}_{0.06}\right]_{\sum 1.48}$ (Grey et al., 2013). It can be seen that if these minerals had the pyrochlore structure, they would both classify as hydrokenoelsmoreites, and are very close in composition to the two phases of the present study. Thus, at least four closely related polymorphs are known from nature in this composition range. The known occurrence of phyllotungstite and pittongite as thin plates suggests that a mineral similar to these may have been the precursor of the HKE phases, which subsequently recrystallized into the pyrochlore structure.

The $6 R$ mineral of this study is not the first reported pyrochlore-structure phase that does not have the full $F d \overline{3} m$ symmetry of the aristotype. There are several examples where the symmetry is lowered to $R \overline{3} \mathrm{~m}$, with $a \sim 7.3 \AA$ and $c \sim 17.3 \AA$ as expected for the conventional pyrochlore structure in this axial setting. This descent in symmetry splits the $A, B$ and $X$ sites such that the phase is crystallographically $(A 1)_{3}(A 2)_{1}(B 1)_{3}(B 2)_{1}\left(X_{1}\right)_{6}(X 2)_{6} Y_{2}$. It may be driven by ordering in $B$ sites, as for the compound $\mathrm{Cs}_{2} \mathrm{Te}^{4+} \mathrm{Te}_{3}^{6+} \mathrm{O}_{12} \equiv \square_{4}\left(\mathrm{Te}^{4+} \mathrm{Te}_{3}^{6+}\right) \mathrm{O}_{12} \mathrm{Cs}_{2}$ (Loopstra and Goubitz, 1986; Mills et al., 2016), which has completely vacant $A$ sites and Cs 
occupying the $Y$ sites, as is typical for very large cations in 'inverse pyrochlores' (Ercit et al., 1993; Atencio et al., 2010). Ordering of $\mathrm{Te}^{4+}$ and $\mathrm{Te}^{6+}$ in a $1: 3$ ratio in $B$ sites lowers the symmetry. Ordering in the $A$ sites leads to adoption of $R \overline{3} m$ symmetry for 'parabariomicrolite' of Ercit et al. (1986), which has now been discredited as identical to hydrokenomicrolite- $3 R$ (Atencio, 2016), while both $A$ and $B$ sites are ordered in the fluoride pyrochlore coulsellite, $\left(\mathrm{Na}_{3} \mathrm{Ca}\right)\left(\mathrm{Mg}_{3} \mathrm{Al}\right) \mathrm{F}_{12} \mathrm{~F}_{2}$ (Mumme et al., 2010). Andrade et al. (2013) described the new mineral species hydroxycalciomicrolite, ideally $\mathrm{Ca}_{1.5} \mathrm{Ta}_{2} \mathrm{O}_{6}(\mathrm{OH})$, as cubic with $a=10.421 \AA$, but in the space group $P 4_{3} 32$. The lowering of symmetry splits $A, B$ and $X$ in the same stoichiometric pattern $(A 1)_{3}(A 2)_{1}(B 1)_{3}(B 2)_{1}\left(X_{1}\right)_{6}(X 2)_{6} Y_{2}$ as occurs for the $R \overline{3} m$ structures, but with a geometrically different arrangement of the distinct sites. In this case, it appears that long-range ordering of $\mathrm{Ca}$ in $A 1$ rather than $A 2$ is responsible for the symmetry change, somewhat analogous to the ordering of $\mathrm{Na}$ and $\left(\square, \mathrm{H}_{2} \mathrm{O}\right)$ the HKE- $6 R$ phase. It is likely that careful study will reveal more low-symmetry pyrochlores and related polysomes, in both natural and synthetic systems.

\section{Acknowledgements}

Jiri Sejkora, Peter Leverett and an anonymous reviewer are thanked for their constructive comments on the manuscript.

\section{References}

Andrade, M.B., Yang, H., Atencio, D., Downs, R.T., Chukanov, N.V., Lemée-Cailleau, M.-H., Persiano, A. I.C., Goeta, A.E. and Ellena, J. (2016) Hydroxycalciomicrolite, $\mathrm{Ca}_{1.5} \mathrm{Ta}_{2} \mathrm{O}_{6}(\mathrm{OH})$, a new member of the microlite group from Volta Grande pegmatite, Nazareno, Minas Gerais, Brazil. Mineralogical Magazine, 81, (in press) https://doi. org/10.1180/minmag.2016.080.116

Atencio, D. (2016) Parabariomicrolite discredited as identical to hydrokenomicrolite-3R. Mineralogical Magazine, 80, 923-924.

Atencio, D., Andrade, M.B., Christy, A.G., Gieré, R. and Kartashov, P.M. (2010) The pyrochlore supergroup of minerals: nomenclature. The Canadian Mineralogist, 48, 673-698.

Birch, W.D., Grey, I.E., Mills, S.J., Bougerol, C., Pring, A. and Ansermet, S. (2007) Pittongite: a new secondary mineral from Pittong, Victoria, Australia. The Canadian Mineralogist, 45, 857-864.
Bruker (2003) SADABS. Bruker AXS Inc., Madison, Wisconsin, USA.

Cameron, J. (1951) The geology of Hemerdon wolfram mine, Devon. Transactions of the Institute of Mining and Metallurgy, 61, 1-14.

Ercit, T.S. and Robinson, G.W. (1994) A refinement of the structure of ferritungstite from Kalzas Mountain, Yukon, and observations on the tungsten pyrochlores. The Canadian Mineralogist, 32, 567-574.

Ercit, T.S., Hawthorne, F.C. and Černý, P. (1986) Parabariomicrolite, a new species and its structural relationship to the pyrochlore group. The Canadian Mineralogist, 24, 655-663.

Ercit, T.S., Černý, P. and Hawthorne, F.C. (1993) Cesstibtantite - a geologic introduction to the inverse pyrochlores. Mineralogy and Petrology, 48, 235-255.

Grey, I.E., Birch, W.D., Bougerol, C. and Mills, S.J. (2006) Unit-cell intergrowth of pyrochlore and hexagonal tungsten bronze structures in secondary tungsten minerals. Journal of Solid State Chemistry, 179, 3860-3869.

Grey, I.E., Mumme, W.G., Vanderah, T.A., Roth, R.S. and Bougerol, C. (2007) Chemical twinning of the pyrochlore structure in the system $\mathrm{Bi}_{2} \mathrm{O}_{3}-\mathrm{Fe}_{2} \mathrm{O}_{3}-\mathrm{Nb}_{2} \mathrm{O}_{5}$. Journal of Solid State Chemistry, 180, 158-166.

Grey, I.E., Mumme, W.G. and MacRae, C.M. (2013) Lead-bearing phyllotungstite from the Clara mine, Germany with an ordered pyrochlore-hexagonal tungsten bronze intergrowth structure. Mineralogical Magazine, 77, 57-67.

Günter, J.R., Amberg, M. and Schmalle, H. (1989) Direct synthesis and single crystal structure determination of cubic pyrochlore-type tungsten trioxide hemihydrate, $\mathrm{WO}_{3} \cdot 0.5 \mathrm{H}_{2} \mathrm{O}$. Materials Research Bulletin, 24, 289-292.

Loopstra, B.O. and Goubitz, K. (1986) The structures of four caesium tellurates. Acta Crystallographica, C42, 520-523.

Mills, S.J., Christy, A.G. and Kampf, A.R. (2016) A review of the structural architecture of tellurium oxycompounds. Mineralogical Magazine, 80, 415-545.

Mumme, W.G., Grey, I.E., Birch, W.D., Pring, A., Bougerol, C. and Wilson, N.C. (2010) Coulsellite, $\mathrm{CaNa}_{3} \mathrm{AlMg}_{3} \mathrm{~F}_{14}$, a rhombohedral pyrochlore with 1:3 ordering in both $\mathrm{A}$ and $\mathrm{B}$ sites, from the Cleveland Mine, Tasmania, Australia. American Mineralogist, 95, 736-740.

Sheldrick, G.M. (2008) A short history of SHELX. Acta Crystallographica, A64, 112-122.

Walenta, K. (1984) Phyllotungstit, ein neues sekundares Wolframmineral aus der Grube Clara im mittleren Schwarzwald. Neues Jahrbuch für Mineralogie, Monatshefe, 12, 529-535.

Williams, P.A., Leverett, P., Sharpe, J.L. and Colchester, D.M. (2005) Elsmoreite, cubic $\mathrm{WO}_{3} \cdot 0.5 \mathrm{H}_{2} \mathrm{O}$, a new mineral species from Elsmore, New South Wales. The Canadian Mineralogist, 43, 1061-1064. 